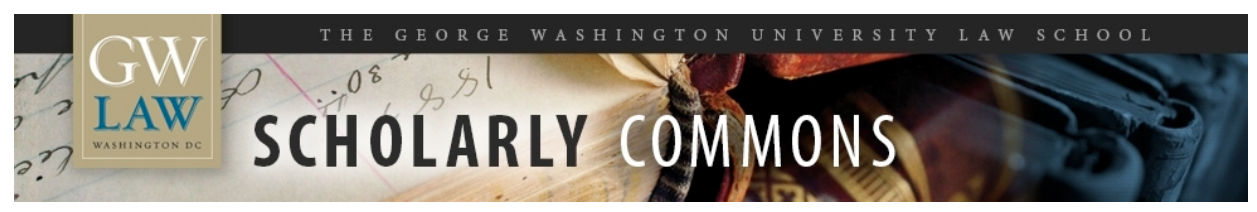

\title{
The Influence of Law and Economics on Law and Accounting: Two Steps Forward, One Step Back
}

Lawrence A. Cunningham

George Washington University Law School, lacunningham@law.gwu.edu

Follow this and additional works at: https://scholarship.law.gwu.edu/faculty_publications

Part of the Law Commons

\section{Recommended Citation}

Lawrence A. Cunningham, The Influence of Law and Economics on Law and Accounting: Two Steps Forward, One Step Back in RESEARCH HANDBOOK ON THE ECONOMICS OF CORPORATE LAW (Claire Hill \& Brett McDonnell, eds., Edward Elgar, 2011-2012)

This Book Part is brought to you for free and open access by the Faculty Scholarship at Scholarly Commons. It has been accepted for inclusion in GW Law Faculty Publications \& Other Works by an authorized administrator of Scholarly Commons. For more information, please contact spagel@law.gwu.edu. 


\title{
The Influence of Law and Economics on Law and Accounting: Two Steps Forward, One Step Back
}

\author{
Lawrence A. Cunningham \\ Henry St. George Tucker III Research Professor of Law \\ The George Washington University
}

\section{Theory}

\subsection{Models and Their Limits}

Under agency theory, shareholders are treated as principals and corporate managers as agents. The theory, elaborated since the 1970s, notes how interests of principals and agents diverge. The cost of controlling that divergence and the cost of the part that cannot be controlled are called agency costs. (Jensen \& Meckling 1976; Triole 2006) Agency costs are limited by various markets, especially capital and corporate control markets. In the law and accounting context, divergence of interests between managers and shareholders can be further reduced by investing in monitoring devices, such as internal controls, board oversight, and independent auditing, and bonding devices, principally transparent accounting and financial disclosure.

To evaluate agency costs and ways to reduce them, scholars sought a proxy to express the shareholder interest and manager actions in relation to it. They found it in the efficient capital market hypothesis $(\mathrm{ECMH})$, cornerstone of modern finance theory. For centuries, shareholders were seen to be interested in maximization of profits and managerial performance was measured in those terms. Beginning in the 1960s, theorists saw stock market price as a proxy for the shareholder interest. They developed the $\mathrm{ECMH}$, a hypothesis that stock price incorporates all public information about a firm, including accounting measures of profits, and supplies a measure of value. The ECMH thus also suggests that stock price incorporated agency costs: companies with higher stock prices are better managed, posing lower agency costs, than those with lower prices (all other things being equal). (Fama 1970; Gilson \& Kraakman 1984)

To assess the meaning of price within the ECMH requires a separate model, called the capital asset pricing model (CAPM). Dating to the 1960s, CAPM assumes investors are risk averse and hold rational expectations about expected returns (meaning expected return is the risk-free rate of return plus compensation for an investment's systematic risk). The latter is measured by the degree of variability of the individual investment versus the market, designated beta. Beta measures relative risk (higher ones signaling greater risk and lower ones lesser risk). CAPM and beta spawn many models to measure the value of a wide variety of capital market assets, beyond equity shares of a corporation, including options and other financial derivatives. (Ross 1976; Roll 1977)

These pillars of modern finance theory have been subjected to voluminous empirical testing for generations. Tests tend to support the models, though constrained by methodological limits, and subject to qualifications that continue to result in considerable debate about their significance and policy implications. (Black 1986) The most dramatic limit is the joint hypothesis problem: tests of the ECMH assume CAPM's validity while tests of CAPM assume 
ECMH's validity. Even so, consensus was reached on two polar forms of the ECMH: most agree that old price histories yield no useful trading information (the weak form) and most reject that inside information lacked value (the strong form). Robust debate concerns whether other public information is reflected in prices, and if so, how quickly, accurately, and meaningfully (the semi-strong form).

Of particular relevance to law and accounting, tests examine the utility of accounting information and the significance of alternative approaches to identical accounting matters. (Griffin 1982; Holthausen \& Leftwich 1983) At issue is whether markets are influenced by accounting forms or pierce them, reducing the importance of particular requirements of generally accepted accounting principles (GAAP). Many tests tend to support modern finance theory: market prices did not appear to be influenced by choices among accounting conventions, such as alternative ways to measure inventory or depreciation. (Sunder 1975) But modern finance theory has not been proven with scientific certitude and many tests leave questions about its descriptive validity. As early as the 1980s, studies showed there is too much securities price volatility for the ECMH to hold. (Shiller 1989) Anomalies have always plagued the hypothesis. (DeBondt \& Thaler 1985) An accounting example is how highly-priced stocks, measured by accounting metrics like the market-to-book ratio, tend to achieve lower average future returns than lower-priced stocks.

Regarding accounting in particular, research studies and the literature also generally carefully emphasize that modern finance theory's implications are limited to the importance of accounting to markets, investors outside the firm. Accounting remains vital within the firm, especially to managers whose performance and compensation is determined by accounting results. This distinction's importance is amplified in positive accounting theory, which helps explain why managers care about accounting measures, despite any stock market indifference, including how debt covenants often are tied to accounting measures. (Watts \& Zimmerman 1990; Walker 2006) Positive accounting theory underscores the persistence of agency costs, though capital markets can limit them.

Compounding debate are periodic market convulsions that seem to defy ECMH's proposition that price changes are due to information changes so that non-events should not induce price changes. (Shleifer 2000; Shiller 2000) Examples include incidents of dramatic market swings lacking justifying cause, such as the stock market crash of 1987, the stock prices of many companies and market indexes amid the technology bubble of the late 1990s and early 2000s, and even the "flash crash" of May 6, 2010 when stock market indexes plunged 10\% in half an hour only to regain half of that by day's end. A spectacular illustration of the limits of CAPM appeared in the 1997 failure of the global hedge fund, Long Term Capital Management, managed by modern finance theory pioneers using its risk models that turned out to be less reliable in practice than in theory. Vast accounting frauds, particularly those at Enron, WorldCom, and other companies in the early 2000s, suggest outer limits of modern finance theory's assumptions and implications. (Gordon 2002)

Challenges to modern finance theory long questioned its assumption of investor rationality. Skeptics, dating to the 1970s and 1980s, consider how investors do not always use information or probabilities but often rely on inferences and hunches. (Kahneman \& Riepe 1988) 
Proponents responded that an economic model's assumptions are irrelevant so long as it enables reliable prediction. But even this as-if rationality may not hold when deviations from expected behavior are systematic rather than random or when it is too costly for other participants to correct the misperceptions. (Cunningham 2002a)

Examples of systematic departures from rationality include biases like loss aversion, manifested in greater reluctance to sell losing rather than winning stocks. (Odean 1998, Kahneman et al. 1990, Benartzi \& Thaler 1995) Of particular relevance to law and accounting is the concept of frame dependence, a bias that leads people to comprehend information differently according to its form of presentation. (Tversky \& Kahneman 1981) Frame dependence suggests that accounting conventions matter to investors, markets and pricing, including how forward-looking information is presented, the use of pro forma information, what prominence cash flow presentations are given, and whether assets are recorded at historical cost or fair value.

These systemic biases even plague professional money managers. Sophisticated arbitrageurs cannot eliminate them since there are not always good substitutes for mispriced securities and there is no assurance that market errors will be corrected before an arbitrage position must be closed out. The upshot is recurring sustained deviations between stock price and business value. Thus, the ECMH may correctly predict "information efficiency," that price impounds public information, while not speaking to whether price is or best approximates value, a notion of "fundamental efficiency." (Gordon \& Kornhauser 1985; Stout 2003) The significance of trading based on information unrelated to fundamental value but which price nevertheless reflects, termed noise trading, remains hotly debated and related policy implications for law and accounting contestable.

\subsection{Theory into Policy}

As with most theories, the literature on both agency theory and modern finance theory cautions that these models are depictions of ideal conditions, not necessarily descriptions of real world activity. (Triole 2006) It is well known that even the best-designed monitoring or bonding devices are both costly and porous. The most well-intentioned corporate boards cannot provide comprehensive oversight, internal controls can be evaded, and even the clearest accounting principles can be manipulated and used to obfuscate financial disclosure. Capital market prices are proxies, sometimes imperfect, and there can be sustained deviations between stock prices and underlying business value. Cautious scholars are thus continually alert to two vital matters.

First, scholars seek to refine theories or assumptions to render them more plausible. Second, they are conscious that theory-reality deviations are inherent in economic modeling-no abstract economic model can perfectly accurately describe or capture reality. Aware of this, people take care to avoid invoking theory overzealously in support of normative policy prescriptions. (Rock 1992) Despite caution, policy makers can miss subtleties and advance policy by invoking theories that should not be taken literally as describing the real world. It is even possible for theorists, charting new terrain, to draw stronger conclusions from early research that later generations of researchers find requires important qualifications. The arc of 
efficient market research suggests a degree of such evolution. Neither point prevents the models from having substantial explanatory power, but do require reconsideration of normative policy implications. (Langevoort 1992; Cunningham 1994)

Ensuing discussion illustrates using a paired example within each of four subjects, securities regulation, standard setting, corporate law, and financial auditing. The first example in each pair exhibits substantial congruence between agency theory and modern finance theory and substantial fidelity in how modern finance theory was used compared to its assumptions and limits. Hence forward-looking disclosure, mandatory cash flow statements, discounted cash flow valuation in appraisal proceedings, and the reputation model of auditing all tend to be supported by both theories, though in varying degrees and with qualifications. The second example in each pair shows considerable divergence and infidelity. Paired illustrations of these more problematic topics are pro forma reporting, fair value measures, the stock market exception to the appraisal remedy, and allowing auditors to discharge duties merely by technical compliance with GAAP.

Before turning to policy implications, it should be noted that those discussed evolved as they did amid debate and development of these theories but this is not to say that theories alone drove the changes. Many factors-economic, historical, political, ideological, and otherwiseaffect policy development and adjustment. That said, there were express invocations of these theories and related literature during debate about policy development. (Lowenstein 1994) That warrants recognizing them as a factor driving results, even if those results could be justified and achieved absent that set of ideas.

\section{Federal Securities Regulation}

\subsection{Forward Looking Disclosure}

Probably the most sweeping policy effect of agency theory and modern finance theory for law and accounting was the adoption of a forward-looking disclosure system by the Securities and Exchange Commission. Through the 1970s, federal securities disclosure laws focused on historical information and generally barred prospective information. (Heller 1961) This policy stance reflected how traditional accounting deals with numerical history. Modern finance theory reoriented attention towards prognostication. If historical accounting information is quickly reflected in stock price and rapidly becomes valueless, what was seen to have value was information that could be used to forecast future financial performance. (Cunningham 2005)

Forward-looking disclosure would transform inside information into public information, enabling it to be priced. In the terms of the three forms of the ECMH, this meant exposing related information to the semi-strong form, where public information is incorporated into price, instead of its strong form, where non-public information is not incorporated into price. Congruently, to the extent that managerial disclosure of forward-looking information constrains discretion, by effectively compelling managers to share internally-generated forecasts and plans, such a regime may contribute to agency cost reduction. (Burton 1974; Kripke 1970)

Despite this compelling combination of theory, considerable controversy accompanied the movement towards a forward-looking disclosure regime and, despite ultimate adoption, the 
issues remain real. Three arguments justify opposing forward-looking disclosure, then and now: (1) since no one can know the future, financial forecasts are inherently unreliable and misleading per se; (2) investors are inclined to rely on information that management supplies; and (3) since it is about the unknown future in stories told by management, it is much easier to manipulate than accounting histories. The primary argument favoring forward-looking disclosure is an underlying premise of modern finance theory about which there is little controversy: investment decisions and valuation judgments are about the future.

The fighting issue is whether investors or managers are better positioned to conduct prognostication. The traditional view, opposing forward-looking disclosure, asserted that management is better at preparing financial information and investors better at interpreting it. Proponents implied the opposite, effectively asserting that managers were better at both preparing and interpreting historical information and suggesting that forward-looking disclosure can reduce agency costs by binding managers to a degree. Proponents also redefined disclosure's target audience, from ordinary to sophisticated investors, a move partially deflecting opponents' argument (2) about propensity to vest managerial forecasts with unwarranted credence. Addressing objection (3), proponents argued that manipulation risk could be neutralized by imposing good faith disclosure duties on managers, an argument likewise supported by agency theory.

Victory in the debate gradually shifted from opponents to proponents, the latter first getting a series of modest SEC endorsements for voluntary forward-looking disclosure and ultimately a variety of mandatory items. (Seligman 1982) Sub-victories concerned target investors. For nearly two decades, managers targeted forward-looking disclosure to institutional investors, including by giving analysts favored information not always given to the public at large. By the late 1990s, however, this practice came to be viewed as pernicious and was outlawed by Regulation FD, requiring that financial forecasting and guidance provided to one investor must be provided to all. ${ }^{1} \quad$ Regulatory resolution of the debate over forward-looking information thus strongly endorsed forecasts, often requiring them, and making them available to all. In addition, good faith duties were imposed, requiring reasonable grounds for predictions and presentation in a suitable format. (Langevoort 1994)

The primary outstanding issue, in the early debate and today, is the reliability of forwardlooking information. (Cunningham 2005) Almost immediately after implementation, the forward-looking disclosure system led to disclosure that was inherently unreliable. Management forecasts routinely were overly-optimistic. Such managerial optimism invariably appears during periods of economic exuberance, and the appearance of bubbles that eventually burst. (Cunningham 2003a). Contemporary examples include the early 2000s technology bubble and housing and financial bubbles later that decade. Such phenomena retrospectively showed some prudence in the SEC's early resistance to allowing forward-looking disclosure. In response to the early period's observed optimism, a series of legal devices were designed to regulate resulting litigation, seeking to distinguish the merely unreliable from the intentionally manipulative. The chief legal tools are safe harbors (statutory, judicial and regulatory) insulating

\footnotetext{
${ }^{1}$ Selective Disclosure and Insider Trading, Federal Register 65, 51716 (Regulation FD).
} 
some information from litigation review, primarily those accompanied by cautionary language about their inherent unreliability. (Coffee \& Sale 2011)

It is difficult to measure the net value of the forward-looking disclosure regime, though it is almost certainly positive. There is evidence that the regime enhanced information quality, increasing the value and relevance of information investors find useful. The cost of that enhancement is some earnings estimates that are overly-optimistic but create market-wide expectations that pressure managers to meet them. Pressure can increase managerial propensity to manipulate accounting reports to meet previous forecasts.

A forward-looking disclosure regime can in some cases increase the risk and frequency of accounting fraud, a form of agency cost. Some interpretations of modern finance theory may discount the significance of the latter costs when asserting that markets are not fooled by forecasts. But when that assumption fails, results include distorted capital allocation and longrun investor losses. On balance, however, the forward-looking disclosure system reduced agency costs generally by generating public information incorporated into price, though at some agency cost in accounting manipulation.

\subsection{Pro Forma Reporting}

A more undesirable byproduct of the forward-looking disclosure system, however, was the expansion of pro forma reporting by management. This refers to financial statement presentations that depart from required accounting conventions. This practice proliferated during the market bubble of the late 1990s and early 2000s, supported by what may have been excessively optimistic interpretations of modern finance theory and failing to emphasize agency costs sufficiently. Experience generally suggested that the practice raised rather than lowered agency costs and the practice was eventually curtailed.

Pro forma reporting was a product of the forward-looking disclosure regime because pro forma reporting was positioned in the context of how management is thinking about its business, past and future. Pro forma reporting depicts historical accounting information but in ways that depart from GAAP. It then uses that information as the basis of generating financial forecasts. It is typically less reliable than GAAP figures such as net income. (Nichols et al. 2005; Fields 1988) Proponents seeking to defend it in terms of modern finance theory would have to rely upon fairly aggressive interpretations of that theory, such as that investors and markets are not fooled by alternative forms of presenting historical financial information.

The theory itself does not necessarily support such bold assertions, however. It does not say pro forma reports omitting categories of expenses that appear in a GAAP-compliant financial statement will not mislead investors. Such information could fairly be regarded as mere noise and, in theory, be ignored and not affect price, if investors can determine actual costs despite pro forma reports omitting them. But pro forma information does influence price, as the reporting that pervaded the Enron era showed, when extensive use of pro forma reporting was correlated with accounting manipulation and financial fraud. (Cunningham 2003a; Gordon 2002) The result was misallocations of capital as well as enormous agency costs. If modern finance theory 
and the ECMH were held to deny that such price-value discrepancies could exist due to pro forma reports, then this episode provides strong evidence against them.

In response to the Enron era's pro forma calamities, the SEC adopted Regulation G to restrict the permissible scope of pro forma reporting, including by requiring any such assertions to be accompanied by the parallel results GAAP would show. ${ }^{2}$ On the other hand, later SEC staff interpretations suggested relaxation of those restrictions. ${ }^{3}$ To the degree that this relaxation is based on faith that efficient markets mean investors are not collectively fooled by pro forma reporting, the position is difficult to defend. Only if markets and investors really do pierce through such formal information to identify substantive reality can one have confidence in condoning its dissemination. It does not seem responsible to invoke modern finance theory to support such assertions of faith in efficient markets, and associated agency costs warrant doubting them.

\section{Accounting Standards}

\subsection{Cash Flow Statement}

Both modern finance theory and agency theory supported the development within accounting of requiring a separate statement of cash flows to augment the traditional balance sheet and income statement. Modern finance theory puts future cash flows at the center of valuation exercises and agency theory supports a cash flow statement because it discourages earnings management. Insofar as using modern finance theory to promote the cash flow statement succeeded in generating additional useful information for investors and markets, it was a resounding success, though some interpretations seemed to go further to elevate cash flows and demote other accounting information.

Accounting's traditional accrual system allocates economic events to discrete fiscal periods based on links to underlying business activity. The accrual system's matching principle implements the links by burdening the income statement with expenses of the period to which they contribute revenue generation (or earlier if this cannot be determined). (Cox 1980) This focus links the income statement with specific managerial stewardship. The accrual system obscures cash flows, something modern finance theory considers central, and the theory's rise drove accounting standard setters in 1987 to require an additional statement, of cash flows, to make cash flows more transparent. ${ }^{4}$ Using cash flow statements along with the income statement and balance sheet can be useful, as to detect earnings management, by comparing reports of accrual income with reports of cash flows. (Krishnan \& Largay 2000) The effect is to discourage managerial accounting manipulations, a way to reduce agency costs.

\footnotetext{
${ }^{2}$ Securities and Exchange Commission, Regulation G, 17 C.F.R. pt. 244 (2005)

${ }^{3}$ Securities and Exchange Commission, Compliance \& Disclosure Interpretations: Non-GAAP Financial Measures (Jan. 15, 2010), available at www.sec.gov/divisions/corpfin/guidance/nongaapinterp.htm.

${ }^{4}$ Financial Accounting Standards Board (1987), "Statement of Cash Flows," Statement of Financial Accounting Standards No. 95.
} 
Modern finance theory and agency theory both thus point to the same policy implication and, generally, there was considerable coherence between modern finance theory's theoretical support of a cash flow statement and the practical achievement of requiring one. But some proponents of modern finance theory pushed its utility a bit further, certainly more boldly than in promoting forward-looking disclosure. In this view, cash became more important than earnings or other accounting metrics as a benchmark of corporate performance and valuation. The assertion that cash, not earnings, moves stock market prices suggests investors pierce accounting conventions that influence reported earnings with laser focus on expected cash flows.

Whatever its plausibility, a troubling consequence of this "cash as king" viewpoint is how it undercuts traditional accounting functions, especially to allocate costs to multiple time periods, like depreciation, inventory accounting, even accounting for stock options. If modern finance theory says market prices result from cash flows, not earnings, this suggests managers lack capital market incentives to manipulate accounting results like earnings. Though this allows for the possibility of managerial manipulation incentives from other sources, like their own contracts and bonuses, it removes an important basis and payoff to accounting scholarship and policy invested in promoting accounting to discourage manipulation. Attention, especially in the academic literature, shifted to positive accounting theory, to explain how managers consider accounting important mainly in terms of compliance with debt and other contracts.

Modern finance theory may not overtly state that managers lack incentives for accounting manipulation, but some interpret it to mean that manipulation will not fool markets, because enough investors pierce accounting conventions to unearth business and economic reality. Yet managerial accounting manipulation does fool markets, whether based on relatively simple matters like whether a telecom company expenses or capitalizes disbursements for line costs (the WorldCom case) or more complex matters like recognizing revenue on contract formation based on forecasted cash flows from an energy-exchange derivative contract (the Enron case). It is therefore imprudent to accept interpretations of modern finance theory that make cash and cash flow the end-all and be-all of corporate financial reporting. At its best, the cash flow statement provides additional useful information and adds a tool to detect for and thus discourage earnings management, reducing agency costs, but should not be exalted. Within those limits, both agency theory and modern finance theory helpfully supported mandatory cash flow statements.

\subsection{Fair Value Measures}

The tools and ideas central to modern finance theory contributed significantly to expanded use of fair value measures in accounting rather than using its traditional cost method, though agency theory may have warranted caution in this expansion. Accounting's traditional measure for most assets is historical cost, justified as observable, objective, and reliable - though its relevance may decline with the passage of time. For certain classes of assets, current market value may be superior to historical cost for both reliability and relevance. Accounting standards have long recognized that possibility in many contexts, such as receivables/payables, the lower of cost or market principle applied to inventory, and pushdown accounting for acquired subsidiaries. 
Beginning in the 1980s and accelerating rapidly during the 1990s, a strong trend began toward making fair value the preferred measure for an increasing variety of assets, a trend strongly influenced by the rising influence and expanding interpretations of modern finance theory. (Siegel 1996) This refers to an elevation of references to market-based prices for capital assets, especially bonds and derivative financial instruments, whose values could increasingly be estimated by tools that trace their roots to modern finance theory's capital asset pricing model. These measures, whether based on actual market prices or implied valuations from models, were increasingly seen not only as more relevant but also potentially more reliable and objective than cost. $^{5}$ Yet markets sometimes freeze, as occurred during the financial crisis of 2008, and valuation models repose considerable discretion in managers. Both points indicate some degree of agency costs associated with fair value accounting that must be compared to agency costs incurred under traditional historical cost accounting.

The choice of asset measurement is vital both for the balance sheet, where the asset is listed, and the income statement, as it can affect both revenue or gains and expenses or losses. A good example concerns fluctuations in the prevailing fair value of marketable securities, including financial instruments and derivatives. Gains and losses are recorded on an ongoing basis, though the securities are not sold. When market prices are rising, managers may find using fair value measures appealing. But when market prices are falling, they may feel the opposite way.

In the years preceding the financial crisis that began in 2008, managers of financial institutions generally tended to favor using fair value measures for instruments like these. But as that crisis unfolded, and as markets for such instruments froze and values accordingly plummeted, they sought changes in applicable accounting standards. That turnabout raised valid questions about agency costs. True, fair value accounting in a broadly collapsing market can magnify the problem into a downward spiral. But the lack of information poses at least some cost to investors. The net balance may not be obvious but caution rather than exuberance should be used when considering the appeal of fair value accounting. More vivid support for this warning appeared in Enron's case. Enron used fair value measures to record revenue on longterm contracts when formed, shredding basic cost-based accounting traditions in favor of predictions, supported by some interpretations of modern finance theory, that misled markets and investors to allocate substantial capital to the fraudulent enterprise. (Cunningham 2003a; Gordon 2002) Agency costs were enormous.

\section{State Corporation Law}

\subsection{Measurements in Appraisal Proceedings}

The rise of modern finance theory drove and corresponded with the broad trend in corporate law towards promoting shareholder value, measured by stock price. Within law and accounting, the trend manifested in a move towards modern finance theory techniques applied in valuation disputes, especially corporate appraisal proceedings. This involved a shift from traditional accounting measurements towards discounted cash flow analysis with reference to

\footnotetext{
5 Financial Accounting Standards Board (2000) "Using Cash Flow Information and Present Value in Accounting Measurements," Statement of Financial Accounting Concepts No. 7.
} 
CAPM's beta to establish risk. (Thompson 1996) In general, agency theory had little to contribute directly to this development. But insights it produces when applied to contexts like forward-looking disclosure and the cash flow statement tend to reinforce the utility of accounting information and to discourage exalting cash flow or analysis of it above traditional accounting information and analysis.

By statute in most states, stockholders who vote against certain transactions are entitled to a judicial appraisal of the fair value of their shares exchanged in the transaction. Before the 1980s, cases tended to estimate value by weighting accounting measures like earnings and assets, along with market price and dividend-based calculations. Beginning in 1983, in Weinberger $v$. UOP, Inc., ${ }^{6}$ discounted cash flow became the fashionable valuation tool, with some courts relegating accounting's traditional tools, based on earnings or assets, to the sidelines. On the other hand, the move to modern finance theory in appraisal proceedings has never been universal or complete: some courts do not adopt it in any measure and courts that do adopt it rarely use it to the exclusion of traditional valuation methods. (Campbell 2003)

During this process of change, the old method came routinely to be described as the "Delaware block method," a term that, interestingly, appears in the cases only after 1983, with each reference to it used for historical explanation only, rather than application. It refers to the exercise of estimating alternative measures of value based on earnings, assets, and market prices and then weighting them according to their relative reliability in particular cases to pinpoint value. The incremental move towards beta-based discounted cash flow valuation reflected dissatisfaction with traditional accounting approaches to valuation. (Fischel 1983; Schaefer 1982) The elements used in the block method were not always reliable indicators of value. The traditional technique ultimately involved a weighting of components that seemed arbitrary, often based on intuitions about how reliable the particular numerical expressions were, rather than whether they were good indicators of value.

As a result, while proponents applaud the judicial trend to adopt modern finance theory, some lament that too few judges do so and even judges who adopt it fail to apply it in a thorough, laser-focused fashion. Thus courts give experts too much leeway and hear evidence that modern finance theory deems irrelevant. They allow debates over whether to use future versus past cash flows, whether to estimate cash flows based on past accounting earnings or some other metric, and allow the discount rate to be set either by reference to modern finance theory or using old-fashioned price-earnings ratios. Yet the virtues of modern finance theory compared to traditional methods should not be overstated. After all, the tools of modern finance theory are susceptible to the same or similar critiques leveled against the traditional block method. They require estimating future cash flows and modeling a terminal value at the estimation period's end, which can be speculative propositions. They also require identifying a group of comparable businesses and extracting their betas, a notoriously judgment-laden process.

It should be unsurprising, then, that few judges in appraisal proceedings limit inquiry solely to predicting cash flows and discounting them to present value using modern finance theory tools like beta. Assets and earnings can and often do matter and analyzing them can and

\footnotetext{
${ }^{6} 457$ A.2d701 (Del. 1983).
} 
often does illuminate value estimates. At least traditional analysis relies on historical realities, measures of assets and earnings, whereas modern finance theory analysis relies on finance forecasts, predicted cash flows over long time horizons using highly-contestable discount rates. If modern finance theory's contribution to valuation in appraisal proceedings were to replace traditional analysis with forecasted cash flows discounted using beta, the net effect would have been negative, not positive. Instead it contributes additional tools judges use flexibly and contextually. To that extent, properly received with judicious caution, modern finance theory has contributed a useful tool to appraisal proceedings.

\subsection{The Stock Market Exception to the Appraisal Remedy}

Though appraisal remedy rights date to the $19^{\text {th }}$ century, a stock market exception to them emerged in the late 1960s, inspired by the rise of modern finance theory, especially the ECMH. The exception, which has generated considerable debate, can be defended on two different grounds, depending in turn on the remedy's purpose. (Manning 1962) If the remedy is to provide dissenting stockholders with liquidity, then the existence of a public market for shares does that adequately. But this rationale for the remedy, though once endorsed, no longer commands wide assent. (Wertheimer 1998) The other, now dominant, rationale for the appraisal remedy is to deliver fair value to dissenting shareholders. The stock market exception can be justified in these terms only if market price is a reliable estimate of fair value, as modern finance theory supposes, at least compared to judicial proceedings. (Seligman 1984) Agency theory may caution against expansive invocation of the exception, however, when those in control of the corporation can manipulate the timing of a transaction to extract rents from other shareholders.

Today, the stock market exception exists in nearly half the states, including Delaware, dominant domicile of large corporations. It is narrowly tailored to deny the appraisal remedy only to certain kinds of transactions involving certain kinds of publicly-traded securities. It is not embraced in the American Bar Association's Model Business Corporation Act, the statutory law in a majority of states, or in the American Law Institute's influential treatise, Principles of Corporate Governance. The Model Act flirted with the exception, adopting it in 1969 but abandoning it in 1978. Participants attributed the 1969 adoption in part to modern finance theory's assertions of capital market valuation prowess and partly to the then-accepted liquidity rationale of appraisal proceedings. (Scott 1968) The 1978 version of the Model Act removed it with an oblique explanation that suggested doubt about both the efficiency theory of markets and the liquidity rationale for the remedy.

As a matter of positive law, then, modern finance theory's influence on the stock market exception to the appraisal remedy has been mixed. It has received an equally mixed reception in related legal scholarship. Some scholars enthusiastically endorse the exception as part of a general dim view of the appraisal remedy itself. (Manning 1962; Fischel 1983) Others equally enthusiastically and generally endorse the remedy and reject the exception, directly challenging modern finance theory's assertions that market prices are good or best value estimates, denying that market prices protect investors. (Eisenberg 1976; Stout 1990) In between are those opposed to invoking the exception when addressing conflict-of-interest transactions, a recognition of the role of agency theory. (Thompson 1995; Seligman 1984) This middle stance appears to be defensible without regard to whether markets are efficient, at least if market prices do not reveal 
the value effects of self-dealing by managers or controlling shareholders. It is an agency cost problem not solved by modern finance theory.

But any serious limitations on the ECMH would warrant more strenuous objections to the stock market exception to the appraisal remedy and, more generally, skepticism about the weight courts should give to market prices in any event. Several factors would warrant judicial subordination of market price to a substantive valuation inquiry. First, cash-out mergers, the most frequent transaction leading to the appraisal remedy, often are effected at a premium to prevailing market price. Some scholars say this raises doubt about market efficiency as a fundamental matter, though this could reflect the distinction between the value of a single share and the value of corporate control. (Wertheimer 1998) Second, market price volatility is significant, so determining at what point price is a good or best estimate of value can be difficult. But an appraisal proceeding requires selecting a particular point. Law may rightly be skeptical of relying on market price at the date of a transaction, since the deal's proponents choose that date and may choose a date they know or believe to represent a low point for the stock not a high point.

Ultimately, the ECMH has had only a narrow and limited impact on the availability of appraisal proceedings to dissenting stockholders, and agency theory makes an important contribution to explaining why. The stock market exception is only recognized in about half the states, although they are states in which large numbers of large corporations are incorporated. Within those, there are statutory limits on the transactions to which it applies. Scholars, and courts, remain cautious about jettisoning the valuation inquiry simply in favor of market price, recognizing inherent problems arising from conflicts of interest, stock market pricing volatility, and insider power to determine the timing of transactions otherwise triggering appraisal rights. Accordingly, while modern finance theory spawns considerable discussion and debate about the appraisal remedy and valuation, an intellectual plus, it has more modest influence on the law governing the availability of this remedy, in part a reflection of offsetting concerns agency theory identifies.

\section{Financial Auditing}

\subsection{A Reputation Model}

Agency theory and modern finance theory both contributed perspectives on financial auditing in what may be called the reputation model of auditing. (Gilson \& Kraakman 1984) Despite theoretical congruity, however, the role of agency costs may have been subordinated to the perceived power of modern finance theory, requiring related policy adjustments. The model supposes that enterprises hire auditors as a device to reduce agency costs. Auditors attest to financial statements in large part based on the auditors' reputation for thoroughness and veracity. Thorough and honest gatekeepers enjoy more credibility, a valuable trait. The more valuable it is, the greater is the risk of reputation loss so that, at some point, no additional incentives are necessary. In addition, the more frequently firms are employed to serve as such gatekeepers, and the larger the number of repeat occasions in which they expect to play these roles, the greater the value. Enterprises pay fees for this credence. Market participants are assumed to appreciate these as valuable signals. (Goldberg 1988; Fischel 1987) 
When operating effectively, such agency cost management can contribute to a market where securities prices tend to converge accurately toward the fundamental value of the related enterprise. They are mechanisms of market efficiency within the modern finance theory framework. Despite considerable theoretical appeal, some of the policy implications drawn from this model remain contestable, particularly concerning the scope of auditor legal liability. (Cunningham 2007) Auditors long have been exposed to legal liability under various state and federal claims, SEC administrative sanctions, and criminal law. Scholars endlessly debate and policy analysts endlessly tinker with the numerous intricacies of this framework to seek its optimal structure. The exact ambit of legal liability may be shaped according to one's views about the role that reputation plays in inducing reliable performance and the importance of auditing to investors and markets - to which agency theory and modern finance theory can contribute.

During the decades of modern finance theory's ascendance, the role of an external agent's reputation and market efficiency assumed greater significance, resulting in a contraction of the ambit of auditor liability risk, by statutes like the 1995 Private Securities Litigation Reform Act (PSLRA) and in Supreme Court opinions. ${ }^{7}$ Alas, financial bubbles and calamities, especially those of the early $21^{\text {st }}$ century, revealed some of the limits of the reputation model of auditing. (Bratton 2003) Many diagnoses have been offered. Some systemic accounts strike at the heart of modern finance theory while revealing the important role of agency costs.

Critiques of efficient market theory gave several examples of widely-known information about agency costs that Enron's stock price ignored-misaligned auditor-firm incentives, extensive audit firm cross-selling of auditing and consulting services, and weak auditor internal controls. (Gordon 2002; Cunningham 2007) More generally, clients pay auditor fees and the auditing industry severely concentrated during the 1990s as a result of firm mergers, which weakens the reputation constraint and yields inferior audit quality. (Cunningham 2004, 2006) But share prices did not reflect any of these publicly-known facts about agency costs.

Accordingly, that episode showed limits of modern finance theory. Even so, the reputation model of auditing, drawing on agency theory, suggested how auditing can promote reliable market pricing.. The enduring issue is how to use these models to inform the optimal level of auditor liability, something that has eluded the best theories for many generations. An important response to the Enron period's revelations was the Sarbanes-Oxley Act of 2002, containing provisions targeted at the agency costs of auditing, including provisions committed to promoting the independence of auditors and audits. While a controversial piece of legislation in many ways, those provisions at least reflected the insights of agency theory and the limits of modern finance theory.

\footnotetext{
${ }^{7}$ For example, Central Bank of Denver v. First Interstate Bank of Denver, 511 U.S. 164 (1994); Stoneridge Investment Partners v. Scientific-Atlanta, Inc., 552 U.S. 148 (2008).
} 


\subsection{Fairly Presents and GAAP Conformity}

It would be a mistake to assume that agency theory and modern finance theory warrant substantially curtailed auditor duties or related legal liabilities, a proposition that appears in an important area of the law governing auditor liability. It concerns the longstanding issue of whether conformity with GAAP is a defense to an assertion that financial statements did not fairly present an enterprise's financial condition and results. Auditors sign opinions saying that financial statements both fairly present an enterprise's condition and results and are prepared in conformity with GAAP. The joint opinion has long stimulated question about whether one of these assertions should be privileged. That is, if it is true that financial statements are in conformity with GAAP, should that discharge an auditor's duties, even if the statements do not fairly present condition or results? Judge Henry Friendly famously answered that question years before the birth of agency theory and modern finance theory, announcing in United States $v$. $\operatorname{Simon}^{8}$ that conformity with GAAP is no defense to assertions of auditor negligence liability if statements do not fairly present.

As agency theory and modern finance theory developed, experts began to wonder about the durability of that legal ruling. During a remarkable period of quiescence on the issue, the SEC and other authorities made some implicit suggestions that it was more important for financial statements to conform with GAAP than to assure a fair presentation. (Cunningham 2003b) These suggestions seemed to address concern that auditor opinions on financial statements that departed from GAAP would more likely amount to a violation of auditor duties. Amid the Enron-era's crisis in financial reporting and auditing, the SEC clarified its position, emphatically denying that conformity with GAAP by itself discharged an auditor's duties.

In a case arising from that period's scandals, concerning WorldCom, the Second Circuit Court of Appeals, the same court for which Friendly wrote, updated Simon and endorsed it in whole. ${ }^{9}$ The case involved a corporate executive's assertions that a criminal indictment was flawed because it did not allege that the asserted accounting was improper under GAAP, arguing that it was necessary for the government to prove violations of GAAP at trial. The court, in an opinion written by Judge Ralph Winter, said a similar argument was made and rejected in Simon and that it saw "no reason to depart from Simon." It acknowledged that GAAP compliance may be relevant to issues of good faith or probative of intent to deceive. But conformity notwithstanding, the applicable statute contemplates only proof of intentionally misleading material statements. Intentionally and materially false financial statement assertions can violate that statute even if in conformity with GAAP.

The court gave an example of how a revenue allocation decision may not have violated GAAP, but if the allocation decision was made deliberately to increase revenue, that could constitute a statutory violation despite GAAP compliance. The financial statements, in other words, might still not fairly present the company's condition or performance. Similarly, some decisions concerning capitalization of line costs were not based on examining the underlying terms of the exchange but on the imperative to meet stated financial targets for the express

\footnotetext{
${ }^{8} 425$ F.2d 796 (2d Cir. 1969) (Friendly, J.), cert. denied, 397 U.S. 1006 (1970).

${ }^{9}$ United States v. Ebbers, 485 F.3d 110 (2d Cir. 2006) (Winter, J.).
} 
purpose of "artificially inflating its stock price." This acknowledges that accounting and financial machinations can cause a stock price to depart from fundamental value, despite modern finance theory. Agency theory suggests that auditing can help reduce agency costs but also that auditing itself presents agency costs and it is probably irresponsible to interpret modern finance theory to mean that either of these can be wholly eliminated.

\section{Concluding Note}

Ongoing debate about the significance and scope of agency costs and modern finance theory continues to have important implications for legal scholarship and education, particularly concerning the resources devoted to corporate finance compared to and law and accounting. The development of agency theory and its application to law did not alter the resource commitment much, though it reshaped much of the content of many courses, including corporations and securities regulation. But the arrival of modern finance theory induced a dramatic reduction in the academy's resource investment in law and accounting and concomitant increased allocation to corporate finance. That shift began in the mid-1970s and accelerated through ensuing decades, with a slight rejuvenation of investment in law and accounting inspired by the Enronera fiascos. (Bratton 1985; Cunningham 2002b; Fiflis 1993; Weiss 1997; Zeff 1971)

These trends seem to elevate the theoretical power and influence of modern finance theory above the practical reality of corporate life and practice. Agency theory and positive accounting theory make clear the vitality of reliably-audited accounting information that some enthusiastic interpretations of modern finance theory tend to discount. The relative shift in the legal academy's commitment to corporate finance compared to law and accounting suggests it mirrors the phenomena captured in the second of each pair of examples in this Chapter, instances presenting divergence between prescriptions of agency theory compared to modern finance theory and of overstatements of the latter's reliability and scope of its conclusions. On this

telling, the influence of law and economics on law and accounting can be approximated by the hoary trope, two steps forward one step backward, though the dance is far from complete. 


\section{References}

Benartzi, Shlomo \& Richard H. Thaler (1995) "Myopic Loss Aversion and the Equity Risk Premium Puzzle," Quarterly Journal of Economics 110, 73-92.

Black, Fischer (1986), “Noise,” Journal of Finance 41, 529-43.

Bratton, Jr., William W. (2003) “Shareholder Value and Auditor Independence,” Duke Law Journal 53, 439-89.

Bratton, Jr., William W. (1985) “Corporate Finance in the Law School Curriculum,” Duke Law Journal 1985, 23760.

Burton, John C. (1974) "Elephants, Flexibility and the Financial Accounting Standards Board," Business Lawyer 29, 151-54.

Campbell, Jr., Rutheford B. (2003) “The Impact of Modern Finance Theory in Acquisition Cases," Syracuse Law Review 53, 1-48.

Coffee, Jr., John C. \& Hillary A. Sale (2011), Securities Regulation, New York: Foundation Press (11th ed.)

Cox, James D. (1980), Financial Information, Accounting and the Law, Boston: Little,Brown.

Cunningham, Lawrence A. (1994) "From Random Walks to Chaotic Crashes: The Linear Genealogy of the Efficient Capital Market Hypothesis," George Washington Law Review 62, 546-608.

Cunningham, Lawrence A. (2002a) “Behavioral Finance and Investor Governance," Washington \& Lee Law Review, 59, 767-837

Cunningham, Lawrence A. (2002b) "Sharing Accounting's Burden: Business Lawyers in Enron's Dark Shadows," Business Lawyer 57, 1421-62.

Cunningham, Lawrence A. (2003a) "The Sarbanes-Oxley Yawn: Heavy Rhetoric, Light Reform (And It Might Just Work)," Connecticut Law Review 35, 915-88.

Cunningham, Lawrence A. (2003b) "Semiotics, Hermeneutics and Cash: An Essay on the True and Fair View," 28 North Carolina Journal of International Law and Commercial Regulation 28, 893-933.

Cunningham, Lawrence A. (2004) "Choosing Gatekeepers: The Financial Statement Insurance Alternative to Auditor Liability," UCLA Law Review 52, 413-75.

Cunningham, Lawrence A. (2005) "Finance Theory and Accounting Fraud: Fantastic Futures versus Conservative Histories," Buffalo Law Review 53, 789-813.

Cunningham, Lawrence A. (2006) "Too Big to Fail: Moral Hazard in Auditing and the Need to Restructure the Industry before it Unravels," Columbia Law Review 106, 1698-1748.

Cunningham, Lawrence A. (2007) "Beyond Liability: Rewarding Effective Gatekeepers," Minnesota Law Review 92, 323-86.

DeBondt, Warner \& Richard H. Thaler (1985) "Does the Stock Market Overreact?," Journal of Finance 40, 793805.

Eisenberg, Melvin A. (1989) “The Structure of Corporation Law” Columbia Law Review 89, 1461-1525.

Fama, Eugene F. (1970) "Efficient Capital Markets: A Review of Theory and Empirical Work," Journal of Finance $25,383-417$. 
Fields, Thomas D. et al. (1988) "An Empirical Evaluation of the Usefulness of Non-GAAP Accounting Measures in the Real Estate Investment Trust Industry," Review of Accounting Studies 3, 103-30.

Fiflis, Ted J.(1993) "Thoughts Provoked by 'Accounting and the New Corporate Law," Washington and Lew Law Review 50, 959-76.

Fischel, Daniel R. (1987) “The Regulation of Accounting: Some Economic Issues,” Brooklyn Law Review 52, 105156.

Fischel, Daniel R. (1983) “The Appraisal Remedy in Corporate Law," American Bar Foundation Research Journal 193, 875-902.

Gilson, Ronald \& Renier Kraakman (1984) “The Mechanisms of Market Efficiency,”Virginia Law Review 70, 549644.

Goldberg, Victor (1988) “Accountable Accountants: Is Third-Party Liability Necessary?” Journal of Legal Studies $17,295-312$.

Gordon, Jeffrey N. (2002) "What Enron Means for the Management and Control of the Modern Business Corporation: Some Initial Reflections," University of Chicago Law Review 69, 1233-50.

Gordon, Jeffrey N. \& Lewis A. Kornhauser (1985) "Efficient Markets, Costly Information, and Securities Research," NYU Law 60, 761-849.

Griffin, Paul A. (1982) "Usefulness to Investors and Creditors of Information Provided by Financial Reporting: A Review of Empirical Accounting Research,” FASB Research Report, 196-207.

Heller, Harry (1961) “Disclosure Requirements Under Federal Securities Regulation,” Business Lawyer 16, $300-20$.

Jensen, Michael C. \& William H. Meckling (1976) "Theory of the Firm: Managerial Behavior, Agency Costs and Ownership Structure, ” Journal of Financial Economics 3, 305-60.

Holthausen, Robert W. \& Richard W. Leftwich (1983) "The Economic Consequences of Accounting Choice," Journal of Accounting and Economics 5, 77-117.

Kahneman, Daniel \& Mark W. Riepe (1988) “Aspects of Investor Psychology," Journal of Portfolio Management 24, 52-65.

Kahneman, Daniel et al. (1990) "Experimental Tests of the Endowment Effect and the Coase Theorem," 98 Journal of Political Economy 98, 132-48.

Kripke, Homer (1970) "The SEC, the Accountants, Some Myths and Some Realities," NYU Law Review 45, 1151 1205.

Krishnan, Gopal V. \& James A. Largay III (2000) “The Predictive Ability of Direct Method Cash Flow Information, Journal of Business, Finance and Accounting 27, 215-45.

Langevoort, Donald C. (1992) “Theories, Assumptions and Securities Regulation: Efficient Markets Revisited," University of Pennsylvania Law Review 140, 851-920.

Langevoort, Donald C. (1994) “Disclosures that 'Bespeak Caution',” Business Lawyer 49, 481-503.

Lowenstein, Louis (1994) "Efficient Market Theory: Let the Punishment Fit the Crime," Washington \& Lee Law Review 51, 925-44. 
Manning, Bayless (1962) “The Shareholder's Appraisal Remedy: An Essay for FrankCoker," Yale Law Journal 72, $223-65$.

Nichols, Nancy B., et al. (2005) "Pro Forma Adjustments to Earnings: Bias, Materiality, and SEC Action," Research in Accounting Regulation 18, 29-52.

Odean, Terrance (1998) “Are Investors Reluctant to Realize Their Losses?,” Journal of Finance 53, 1775-98.

Rock, Edward B. (1992) “Preaching to Managers,” Journal of Corporation Law 17, 605-714.

Roll, Richard A. (1977) “Critique of the Asset Pricing Theory's Tests,” Journal of Financial Economics 4, 129-76.

Ross, Richard (1976) “The Arbitrage Theory of Capital Asset Pricing,” Journal of Economic Theory 13, 341-60.

Schaefer, Elmer J. (1982) "The Fallacy of Weighting Assets Value and Earnings Value in the Appraisal of Corporate Stock," Southern California Law Review 55, 1031-96.

Scott, Willard P. (1968) "Changes in the Model Business Corporation Act," Business Lawyer 24, 291-304.

Seligman, Joel (1984) “Reappraising the Appraisal Remedy,” George Washington Law Review 52, 829-71.

Seligman, Joel (1982) Transformation of Wall Street, Boston: Houghton Mifflin.

Shiller, Robert J. (1989) Market Volatility, Cambridge, Mass.: MIT Press.

Shiller, Robert J. (2000) Irrational Exuberance, Princeton, NJ: Princeton University Press .

Shleifer, Andrei (2000) Inefficient Markets, Oxford: Oxford University Press.

Siegel, Stanley (1996) "The Coming Revolution in Accounting: The Emergence of The Fair Value as the Fundamental Principle of GAAP," Wayne Law Review 42, 1839-62.

Stout, Lynn A. (2003) "The Mechanisms of Market Inefficiency: An Introduction to the New Finance," Journal of Corporation Law 28, 635-69.

Stout, Lynn A. (1990) "Are Takeover Premiums Really Premiums? Market Price, Fair Value, and Corporate Law," Yale Law Journal 99, 1235-96.

Sunder, Shyam (1975) "Stock Price and Risk Related to Accounting Changes in Inventory Valuation," Accounting Review 50, 1305-15.

Thompson, Robert B. (1995), "Exit, Liquidity, and Majority Rule: Appraisal's Role in Corporate Law," Georgetown Law Journal 84, 1-60

Thompson, Jr., Samuel C. (1996) "A Lawyer's Guide to Modern Valuation Techniques in Mergers and Acquisitions,"Journal of Corporation Law 21, 457-540.

Triole, Jean (2006) The Theory of Corporate Finance, Princeton, NJ: Princeton University Press.

Tversky, Amos \& Daniel Kahneman (1981)“The Framing of Decisions and the Psychology of Choice," Science 211, 453-58.

Walker, David I. (2006), "Financial Accounting and Corporate Behavior," Washington and Lee Law Review 64, 927-1009, 
Watts, Ross L. \& Jerold L. Zimmerman (1990) "Positive Accounting Theory: A Ten Year Perspective," Accounting Review 65, 131-56.

Weiss, Elliott J. (1997) "Teaching Accounting and Valuation in the Basic Corporation Law Course," Cardozo Law Review 19, 679-95.

Wertheimer, Barry M. (1998) “The Shareholders’ Appraisal Remedy and How Courts Determine Fair Value,” Duke Law Journal 47, 613-715.

Zeff, Stephen A. (1971) “Accounting for Business Lawyers,” Tulane Law Review 46, 358-62. 